\title{
JOURNAL OF BORNEO-KALIMANTAN(JBK)
}

\section{Rural Women Entrepreneurs Enrolment into Sustainable Supply Chain Networks: From Actor Network Theory Perspective}

\author{
Sidikat Shitu ${ }^{1}$ and Rohaya Mohd-Nor ${ }^{2 *}$ \\ ${ }^{1}$ Ibrahim Badamasi Babangida University, Nigeria \\ ${ }^{2}$ Faculty of Economics and Business, Universiti Malaysia Sarawak, 94300 Kota Samarahan, Sarawak \\ *Corresponding author \\ Email address: mnrohaya@feb.unimas.my
}

\begin{abstract}
Rural women entrepreneurs in the West African sub-region are focal actors at the bottom of many commodity supply chains. The positions that they occupy in supply chain are susceptible to many forms of sustainability challenges that can obstruct and discourage them from efficiently participating in global supply chains. Despite the critical role of rural women entrepreneurs in the West African subregion has been acknowledged by many, yet the majority of them have not been participated in responsible and sustainable supply chains. In view of these issues, multi-stakeholders are required to collaborate and intervene by developing processes of enrolling rural women entrepreneurs into sustainable supply chain networks. This study presents a case study related to an exploration of the enrolment process utilizing the four moments of translation of the Actor Network Theory (ANT) in the context of the shea butter industry with a cross-border supply chain network. The research found that the enrolment process is shaped by the collaborative relationships within the external context which comprises of several influential stakeholders. Sustainability standards are found to have great potential to serve as an obligatory passage point to transmit sustainability principles to the women within and outside the traditional supply chain networks.
\end{abstract}

Keywords: Rural Women Entrepreneurs, Sustainable Supply Chain, External Stakeholders, Actor Network Theory, Sustainability Standards

\section{INTRODUCTION}

Researchers posit that stakeholders involved in the supply chain of agricultural commodities in the sub-Saharan Africa needs to respect and practice responsible and sustainable supply chains. This position is predicated upon the growing social, economic and environmental sustainability challenges found in the supply chains of the stakeholders (Schaffnit-Chatterjee et al., 2014; Anderson \& Van der van, 2016; Adekunle et al., 2016). The African shea butter industry is one of such industries that is not without the challenges of sustainability. Hence, there is the need for urgent intervention strategies aimed at addressing these challenges especially for actors in the supply chains at the point of commodity supply (Carter \& Rogers, 2008; Klassen \& Vereecke, 2012). Additionally, it is posited that adoption, transmission and use of sustainability standards is the basis for achieving responsible and sustainable supply chain in a number of organised commodity supply chain networks such as the coffee, cocoa and shea butter (Gulbrandsen, 2008; Manning \& Von Hagen, 2010, Elias \& Saussey 2013). Nevertheless, the above submissions are not all-encompassing because not every actor or groups of actors who participate in commodity supply chain are actually and properly enrolled into sustainable supply chain networks (Manning \& Von Hagen, 2010). More so, even though many researchers are of the opinion that responsible and sustainable supply chain is one of the prerequisites for poverty mitigation, respect 
for human rights and environmental protection (Noumi et al., 2013), more still needs to be done within the context of the West African shea butter industry.

\section{OBJECTIVE}

The objective of this paper is to present how sustainability programs designed to enrol supply chain actors towards the practice of sustainable supply chain, using a case study, can be achieved. This study examined a conventional shea butter supply chain network where numerous actor participates for their livelihood. Actor Network Theory (ANT) is used as a guided theory that provides analysis on the enrolment of rural women entrepreneurs into sustainable supply chain networks.

ACTOR NETWORK THEORY AND RELEVANT THEORETICAL VIEWS

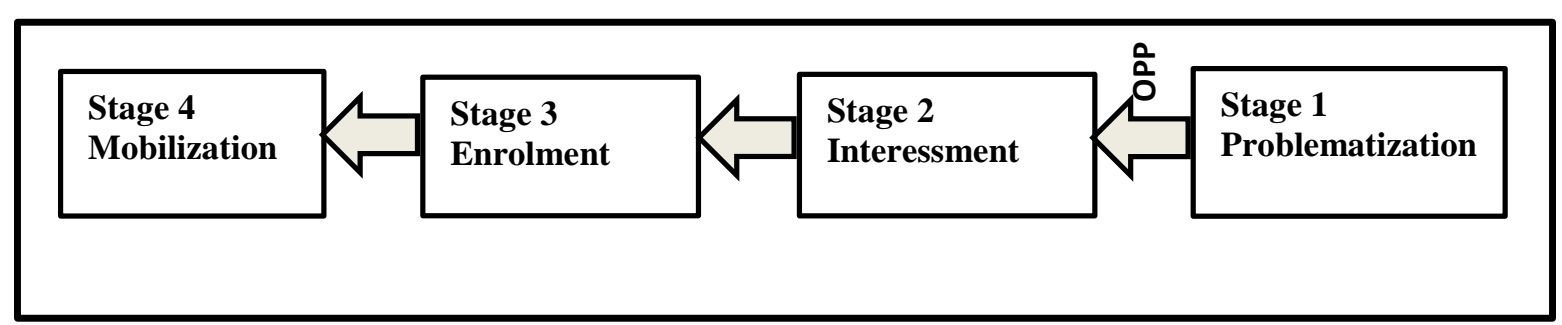

Figure 1. The Four Moments of Translation (Callon, 1986)

Several studies have shown that enrolment of supply chain actors into sustainable supply chain network is essential to achieving sustainability in supply chains (Manning \& Von Haggen, 2010; Klanssen \& Vereecke, 2012). Drawing on these assertions from past studies, we attempt to expand a theoretical framework underpinning the four translation elements of the Actor Network Theory (ANT) to explore the enrolment process. We adopt this theoretical views for three main reasons as follows. Firstly, this is a framework that conceptualizes formation of heterogeneous network as a phenomenon that would occur of the temporality of time. Secondly, as suggested by Latour (1988), supporters of ANT do not anticipate the effect actors will have on network in anticipation. Thirdly, the success of enrolment greatly depends on the participation of actors within and outside the network.

Central to the understanding and appreciation of ANT is the concepts of sociology or moments of "translation". It is the method of obligatory collaboration by which actors who are not initially in a network enrol one another into heterogeneous network, sustain their presence in an "actor-world" through multi-faceted interactions, relationships and collaborations. Another procedure of translation is the approach of interpreting the involvement of actors in the actor-world by creating an obligatory passage points (Callon, 1986), through which actors transverse without necessarily following their contribution to the overall functioning of the actor-world. The outcome of collective translation of actants is to ensure the unity of the actor-world. Therefore, a supply chain in disparity, is not an entity, but a concept that is used to describe collective translation or could be termed hybrid network of aligned interest, which includes people, organisations and standards (Latour, 2005; Mohamed et al., 2013). This assertion of translation is supported by Callon (1986) submission, where he suggests that the translation process must pass through the four following stages i.e. problematization, interessement, enrolment and mobilization.

\section{METHODOLOGY}

This study employs a qualitative research design, and use several methods including case study and observation to obtain data from participants selected from within the internal context and external context of the shea butter industry. The participants within the internal context comprised of the local buying agents and the rural women entrepreneurs who reside in the villages. The participants from the external context comprised of the government and NGO officials. 


\section{FINDINGS}

The translation process revealed that, the external actors are the most important influencers of change. Their decisions, actions and roles in regulatory framework shape sustainability context in the shea butter industry. The identified external actors that were found to strongly influence the supply chain networks are the Nigerian Export Promotion Agency, Niger State Commodity and Export Promotion Agency, German Technical Cooperation, Social Development Department (SDD) of the Borgu Local Government and Global Shea Alliance. These external actors identified the problems and agreed that all stakeholders in the industry must comply with the sustainability guidelines provided by the Deutsche Gesellschaft fur Internationale Zusammenarbeit (GIZ). In this regard, the external actors accepted to align their interest together and gear their roles towards developing sustainable supply chain network. The external actors identified SDD as the closest external actor to the rural women entrepreneurs on the Nigerian side. These actors aligned their actions through the roles played by the Director of SDD and her team.

\section{Problematization stage}

In this research, the Director of SDD and her team whom have been trained by the state government and nongovernmental organizations are treated as a single entity working towards ensuring that suppliers act in a sustainable manner in the case study. Undertaking this view, ANT asserts that this means punctualization. SDD and the other external actors have identified the sustainability issues and provided guidelines capitalizing on the use of obligatory passage point to facilitate sustainable supply chain practices that can lead to improvement in the livelihood of the rural women entrepreneurs. The strategy deployed was mentioned by the Director of SDD as follows:

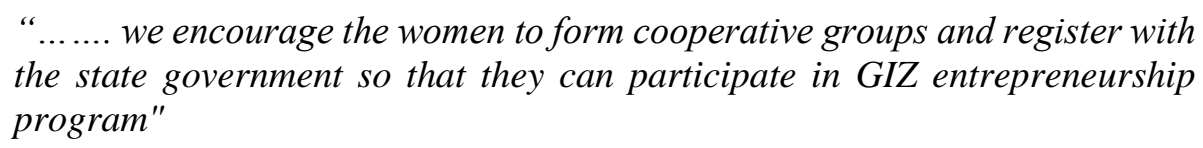

\section{Interessment stage}

The outcomes from the study revealed that after cooperative groups were formed, SDD convinced the rural women entrepreneurs to comply with the sustainability guidelines and transmitted the guidelines to non-cooperative members since women share the same traditional market and are closely linked with one another. Based on this, the rural women entrepreneurs were punctualize as single entity in the supply chain networks. The negotiation began with deliberation on the benefits that would be derived by aligning their interest with that of the external actors. For instance, if they act responsibly by obeying the principles of sustainability standards and guidelines, they can enjoy loan facilities to purchase modern equipment for processing.

\section{Enrolment stage}

The enrolment of the rural women entrepreneurs is still on-going. The strategies deployed by SDD have shown some positive progress, despite facing many challenges particularly with the enrolment of the large numbers of rural women entrepreneurs who were disorganized. Interestingly, some rural women entrepreneurs have begun forming cooperative associations. Those who were not yet part of any cooperative group however expressed their approval by agreeing to join a new cooperative group or join the existing group.

\section{Mobilisation stage}

SDD assumed the role of the spokesperson for the external actors; they continued to mobilise other inactive rural women entrepreneurs in the case study. At this point, SDD has been vigorously involved in promoting sustainable supply chain with the support from the other external actors. 


\section{RESEARCH IMPLICATIONS}

At present, discussions on sustainability in commodity supply chains and the recommendation that implementation, adoption and use of sustainability standards should be used to achieve sustainability in supply chains are gaining serious attention in the literature (Anisul Huq et al., 2014; Agrawal \& Sharma, 2015). However, much of these studies did not consider the important role of weak actors such as the rural women entrepreneurs. Current research have given much attention towards the organized network groups and strong actors (Manning \& Von Hagen, 2010) but largely ignored the weak actors. Reflecting on this gap, it is important to understand the impact of weak actors and in the context of shea butter industry of Nigeria, the roles played by rural women entrepreneurs must be acknowledged. This study, based on the research findings, further asserts that the participation of multistakeholders, particularly the role of external stakeholders can greatly influence the development and practice of responsible and sustainable supply chains. The participation of multi-stakeholders should not viewed as limited to the translation process because their roles and relationships can bring dynamics that further shape the enrolment process, particularly in the establishment of a responsible and sustainable supply chain network.

The problematization and transmission approach is an idea conceived by the standard setting organization and then this idea was diffused to the federal and the state governments. Subsequently, the state government typically championed and transmitted the idea to the social development department (SDD) for implementation phase. Following the theoretical view the Actor Network Theory, the obligatory passage point (OPP) becomes necessary. Callon (1984) suggested that in order to achieve a stable relation and a target orientation, the actor has to set an "obligatory passage point" to channel all interest to one direction. In the case study, it was found that because of the cross border supply chain activities among the supply chain actors that include producers and suppliers of shea products within the boundary of Borgu-Nigeria and Parakou-Benin Republic Supply Chain Network, the social development department engaging in the problematization process may not necessarily possess much influence on the actors in Benin Republic because of their limited authority.

This study also found that many rural women entrepreneurs were treated less important in the existing supply chains of the industry. It further argues that in the context of developing responsible and sustainable supply chains, the enrolment process of rural women entrepreneurs was politically and culturally motivated. For example in the research, this study found that many villages within the ten political wards in Borgu had women entrepreneurs participated in the supply chain of shea products. Unfortunately, these women entrepreneurs did not belong to any organized group in the supply chain networks and this restricted the intervention efforts of the external actors to enrol them in the devised initiatives. With the lack of presence of non-governmental organizations in the supply chain networks, SDD has to represent the interest of other external actors such as the non-governmental organizations. GIZ at the time of the study, was the only non-governmental organization that has been actively involved in the shea butter industry in Nigeria that works closely with the government agencies and the community gatekeepers to educate the communities on the need for sustainability of the shea butter industry. However, GIZ has scaled down its activities because of the capability of the local authority to take over shea related intervention programs (Ebayaya, 2014).

The collaborative effort and presence the other external actors are important in supporting the mobilization and enrolment of the rural women entrepreneurs who are weak, widely spread and do not belong to any organized networks within the supply chain networks. This study found that with the forming of new and organized networks, these women entrepreneurs could be enrolled through effective collaboration in the networks. This is the translation process, according to the views of Actor Network Theory, and this process can enable these women to participate in the responsible and sustainable supply chains including global supply chain activities and processes. In this context, policy-makers need to devise effective interventions that can include all actors regardless of whether they belong to an organized network or not in the industry supply chain networks. 


\section{CONCLUSION}

This study presents the research outcomes about |the roles of external actors in facilitating the process of enrolling rural women entrepreneurs into sustainable supply chain networks, using the four stages of translation aspect of Actor Network Theory. The process of how rural women entrepreneurs get involved into sustainable supply chain networks were highlighted. Their relationship with the strong suppliers and the external actors were examined based on the level of information sharing, collaboration and networking. It was found in the study that there were incidences of malpractices and unethical behaviors among strong suppliers within the existing traditional supply chain networks that created strong impact on rural women entrepreneurs. The most notable one was the practices and behaviour of the exporters across the border region. The implication of this situation is that the increasing unethical practises in the supply chain networks will strongly influence the enrolment process. Further, this study found that the rural women entrepreneurs' full enrolment depending on their relationship with the strong suppliers who control the entire supply chain networks. Finally, using Actor Network Theory, this study asserts that the implementation, adoption and use of sustainability standards which represents the Obligatory Passage Point (OPP) for all actors can create enabling environment for the enrolment of rural women entrepreneurs into sustainable supply chain networks. In this context, OPP will shape the problematisation process as well as will allow actors to align their interest without the necessity to be influenced in the interessment stage.

\section{REFERENCES}

Adekunle, A. A., Ellis-Jones, J., Ajibefun, I., Nyikal, R. A., Bangali, S., Fatunbi, A. O., \& Angé, A. (2016, April). Agricultural innovation in Sub-Saharan Africa: Experiences from multiple stakeholder approaches. Accra, Ghana: Forum for Agricultural Research in Africa (FARA).

Agrawal, R. \& Sharma, V. (2015). Social sustainability practices in the supply chain of Indian manufacturing industries. International Journal of Automation and Logistics, 1(3), 211-233.

Anderson, S., \& Van der Van, C. (2016). Towards Inclusive Trade: How to Unlock the Trade Potential of Emerging Agricultural Enterprises in Sub-Saharan Africa. Society of International Economic Law (SIEL), Fifth Biennial Global Conference, July 7-9, 2016. Available at SSRN: https://ssrn.com/abstract=2844062

Anisul Huq, F., Stevenson, M., \& Zorzini, M. (2014). Social sustainability in developing country suppliers: An exploratory study in the ready-made garments industry of Bangladesh. International Journal of Operations \& Production Management, 34(5), 610-638.

Callon, M. (1984). Some elements of a sociology of translation: domestication of the scallops and the fishermen of St Brieuc Bay. The Sociological Review, 32(S1), 196-233.

Callon, M. (1986). The sociology of an actor-network: The case of the electric vehicle. In mapping the dynamics of science and technology,19-34. London, UK: Palgrave Macmillan.

Callon, M. (1989). Society in the making: The study of technology as a tool for sociological analysis. In Bijker, W. E., Hughes, T. P. and Pinch, T. (eds.) The Social Construction of Technological systems. Cambridge Massachusetts: MIT Press, p. 83-103. 
Carter, C. \& Rogers, D. S. (2008). A framework of sustainable supply chain management: moving toward new theory. International Journal of Physical Distribution and Logistics Management, 38(5), 360-387.

Elias, M. \& Saussey, M. (2013). The Gift that Keeps on Giving: Unveiling the Paradoxes of Fair Trade Shea Butter. Sociologia Ruralis, 53(2), 158-179.

Gulbrandsen, Lars H. (2008). Accountability Arrangements in Non-State Standards Organisations: Instrumental Design and Imitation. Organisation, 15, 563-583.

Klassen, R. D. \& Vereecke, A. (2012). Social issues in supply chains: Capabilities link responsibility, risk (opportunity), and performance. International Journal of Production Economics, 140(1), 103-115.

Latour, B. (1988). 1988: The pasteurization of France. Cambridge, MA: Harvard University Press.

Latour, B. (2005). Reassembling the social: An introduction to actor-network-theory. Oxford, UK: Oxford university press.

Law, J. (1992). Notes on the theory of the actor-network: Ordering, strategy, and heterogeneity. Systems practice, 5(4), 379-393.

Manning, S. \& Von Hagen, O. (2010). Linking local experiments to global standards: How project networks promote global institution-building. Scandinavian Journal of Management, 26(4), 398-416.

Mohammed, F., Boateng, S., \& Al-hassan, S. (2013). Effects of Adoption of Improved Sheabutter Processing Technology on Women's Livelihoods and their Microenterprise Growth. American Journal of Humanities and Social Sciences, 1(4), 244-250.

Noumi, E. S., Dabat, M. H., \& Blin, J. (2013). Energy efficiency and waste reuse: A solution for sustainability in poor West African countries? Case study of the shea butter supply chain in Burkina Faso. Journal of Renewable and Sustainable Energy, 5(5), 053134.

Schaffnit-Chatterjee, C., Lanzeni, M. L., AG, D. B., \& Hoffmann, R. (2014). Agricultural value chains in Sub-Saharan Africa. From a development challenge to a business opportunity. Deutsche Bank Research, Frankfurt. 